\title{
Sandalwood Oil
}

National Cancer Institute

\section{Source}

National Cancer Institute. Sandalwood Oil. NCI Thesaurus. Code C107365.

The oil extracted from the heartwood of Santalum album. Sandalwood oil is used in perfumery, aromatherapy and skin care. 